\title{
Assimilation as a Co-articulation Producer in Words and Pronunciation Problems for Turkish English Teachers
}

\author{
Mehmet Demirezen ${ }^{1}$ \\ Hacettepe University
}

\begin{abstract}
The aim of this research is to diagnose and help students overcome their problems through practice activities in English Language Education Departments in Turkey. This paper measures the perception of co-articulatory information in terms of consonant-to-consonant relations in the structure of vocabulary items and affixes of English. Thirty eight freshmen who are presently studying in the department of English language education at Hacettepe University are the participants, who were given a pretest on vocabulary items that include 25 questions, with five alternatives for the diagnosis of the secondary articulations in the words. Thereafter, a three-hour intense teaching and practicing process took place. After two weeks, the participants were given a posttest that included new vocabulary items not asked in the pretest. Results of data analysis revealed that co-articulation and secondary articulation connection in the creation of assimilations constituted a serious pronunciation problem due to consonantal and vowel assimilations for Turkish students of English Language Education. Results also indicated that the perception of assimilation is weak at the end of the pretest, but there is a remarkable development after the instruction on secondary articulation and coarticulation in relation to the perception of assimilation in connected speech in English utterances.
\end{abstract}

Keywords

Assimilation • Anticipatory co-articulation $\bullet$ Co-articulation $\bullet$ Perseverative co-articulation •

Pronunciation fossilization $\bullet$ Secondary articulation

1 Correspondence to: Mehmet Demirezen (PhD), Department of Foreign Language Education, Faculty of Education, Hacettepe University, Ankara, 06800 Turkey. Email: md49@hacettepe.edu.tr

Citation: Demirezen, M. (2016). Assimilation as a co-articulation producer in words and pronunciation problems for Turkish English teachers. Educational Sciences: Theory \& Practice, 16, 477-509. 
Coarticulation incident in pronunciation and phonology is probably the most important and common feature of connected speech in all languages. In fact, it is ubiquitous in real speech and connected speech, creating dynamic transitions between or among adjacent segments, both within words, across words and word group-like phrases, clauses, and sentences, which make the speaking process perhaps easier for all talkers. Co-articulation is extremely pervasive cross-linguistically, which means that it is seen in all languages of the world. According to Farnetani (1999), some type or degree of co-articulation could be found in all languages of the world. Secondary and co-articulations triggered by assimilation, therefore, seem to be common in all languages. For example, in Turkish the word "kar" means "snow", but a word like "kâr", which has a palatalized vowel as a secondary articulation means benefit that changes the meaning of the word. So, secondary articulations can also exhibit dialectal pronunciation differences; for example, the word "dual" /dju:əl/ has got a palatalized /d/ phoneme in British English, but the same case is not encountered in North American English (NAE) where the pronunciation of the same word comes out as /du:əl/ without a palatalized /d/ phoneme. So, secondary articulations can create dialectal pronunciation shifts which can be confusing to students of the English language.

Exhibiting different patterns and degrees of various types of co-articulation, almost all languages display a coarticulatory incident in chain reaction interactions; therefore, co-articulation, like secondary articulation, is a trait of universal characteristics of speech production in connected speech. Coarticulation between sounds will always result in the positions of some parts of the vocal tract being greatly effected, whereas others will not be affected as much by neighboring targets (Ladefoged, 2009, p. 9). Coarticulation, which is in essence the perception of controlled acoustic variables by human brains, is a crucial issue in human speech behavior. In its general sense, the term co-articulation refers to an articulatory situation in which an isolated phoneme is influenced by a preceding or following phoneme, and becomes more like it. It occurs as physiological movements; and different articulators and speech production processes are involved in the course of speech, combined with one another by means of sub-phonemic variations with different timing patterns.

The overlapping effect and gesture of two articulators upon each other is also called co-articulation. Co-articulation "refers to the transition from one gesture to another, whereby the different articulation gestures combine with different timing patterns" (Hardcastle \& Hewlett, 2006). In addition, the occurrence of co-articulation can be diagnosed by electropalatography (EPG) and photography (Hardcastle \& Hewlett, 2006). Co-articulation results in similar productive assimilatory mechanisms and similar patterns of co-articulatory direction. For this reason, it is taken as the automatic effect of speech production on accuracy, intelligibility and fluency. 
There are consonant-to-vowel, vowel-to-consonant, vowel-to-vowel co-articulations (Magen, 1984) and many consonant-to-vowel, vowel-to-consonant, consonant-to consonant, and vowel-to-consonant-to-vowel (Demirezen, 1986) assimilations, which increase the number of the allophones of phonemes and sounds in the languages of the world in phonetic variability. When it comes to the English language, their perception in colloquial speech may be troublesome to a great majority of non-native learners of English. That's why it is worthwhile to explore a topic like co-articulation when it comes to teaching English as a foreign language. Co-articulations become even harder to perceive and then to articulate for non-native teachers when co-articulations co-occur with secondary articulations, together termed multiple articulations. In such cases, nonnative teachers transfer their L1 pronunciation habits to the L2 and develop a pidginized pronunciation. "Transference from one speaker's use of language to another speaker's use of language can be characterized as a contamination factor in the use of the L2" (Nel \& Müller, 2010, p. 636). A contaminated pronunciation efficiency is undesirable and ought to be avoided in the speech of the non-native English teachers.

In fluent speech, the phonetic context is a potential manipulator over the acoustic realization of the phonemes. The phenomenon, called co-articulation, is highly dependent on the intrinsic inactivity of the human speech articulatory system. During the act of speech, the transition from one phoneme to another takes place effortlessly in a continuous way. Such articulatory processes constantly facilitate the interactivities between vocal effort and speech intelligibility. The influence of the phonetic context on the realization of phonemes can even assist in formation of pronunciation variants called allophones, which signal that the target phoneme can be reserved, or a different phoneme can come into being. Moreover, regional accents also provoke variations in pronunciation (Demirezen, 1986; Jenkins, 2002; Kachru, 1996; Merino, 1997). For this reason, teachers must know of the changes of pronunciations in two major native dialects of English, such as between North American English (NAE) and British English (BrE). There are of course also other varieties such as Canadian and Australian dialects of English, which are additionally used in foreign language teaching and learning. Use of a dialect or dialects is additionally related to teacher identity. Accordingly, teacher identities could be "described as the way teachers feel about themselves professionally, emotionally and politically, given the conditions of their work" (Jansen, 2000, p. 242).

It is argued here that faulty pronunciation of non-native English teachers in the field of foreign language Education, due to inefficient co-articulation in pronunciation, cannot be ethically accepted at this stage in the development of EFL teacher training. There are electronic dictionaries, e-books, and pronunciation teaching sites on the internet, which require some mastery of computer technology by means of which trainee teachers can develop themselves as autonomous learners. Then, they can 
engage their students in refining their pronunciation skills. It must be noted that teachers ought to "capture the attention of learners pertaining to primary, secondary, and coarticulations during a lesson, irrespective of their learning style, and if the attention of learners tends to wander, teachers ought to be able to shift rapidly to a new activity to recapture it" (Bester \& Brand, 2013, p. 3). This manner of practice is both a professional and ethical necessity.

English is one of the most prevalent international languages of education, science, business, politics, international relations, communication, and culture, where English language teaching is currently experiencing a widespread economic boom in the areas of EFL, ESL, SLA, TEFL, EAL, ELF and EIP. Just as in other countries of the world, even almost all African and Turkic countries make the teaching and learning of English a priority in their national education policies. However, to improve the quality of English instruction, qualified language teachers are indispensable. African language and native speaker teachers of English, as well as teachers with other Turkic nationalities, can aid the progress of those factors that affect the quality of English language teaching and learning. In terms of teacher education, co-articulations and secondary articulations are the building blocks of the kind of strength of pronunciation and intonation that pave the way a professional level of fluency. Otherwise, coarticulations and secondary, articulations which are curtailed by consonantal and vowel assimilations, will keep worsening the pronunciation and intonation of the non-native language learners.

Co-articulation, in essence, is a joint articulation of two or more speech sounds which produce assimilatory impacts upon one another during the act of articulation. During the process of the articulation of these sounds, if these sounds produce articulatory influences upon each other, secondary articulations come into being as additional sound features without which an accurate articulation of the related sounds cannot be established. Such articulations are mostly not paid attention to during professional training periods. That's why the most vulnerable ascpects of non-native teachers are pronunciation and intonation. The accuracy, intelligibility, and fluency of native or non-native teachers' qualified pronunciation and intonation begin with the correct co-articulations and secondary articulations, whose definitions are already given, that interact between or among vocabulary items, phrases, clauses, and sentences.

\section{Review of Literature}

In phonetics, in the process of assimilation a speech sound gets to be similar or identical to a neighboring sound under certain magnetic charm and sound attractions. As indicated by Hardcastle and Hewlett (2006), Coarticulation Theory cites the assimilation types are crucial promoters and curtailers of secondary and coarticulations. 
So, there are direct relations between assimilation types and secondary and coarticulation formations in the structures of pronunciation and intonation in speech. If such assimilatory formations are not studied properly, the result will be inaccurate, unintelligible, and faulty fluency. Assimilations, as Crystal (2008) indicated, may be of two types: partial and full assimilations. In a simple case of assimilation, features of adjacent sounds may combine together, and in this medium one of the sounds may not be pronounced (Edwards, 2003). According to Collins and Meesi (2013), in many cases of assimilation there is a bidirectional exchange of articulatory traits and that's why assimilations can occur as progressive and regressive types. Similarly, Knight (2012) claims that assimilation is very common in connected speech; therefore, connected speech processes have the potential to cause misunderstandings via sound assimilations. Assimilation is a potential problem-causer in teaching pronunciation (Burleig, 2011; Collins \& Meesi, 2013; Crystal, 2008; Edwards, 2003; Knight, 2012; Roach, 2009).

In fact, assimilation and its types constitute a global issue. For example, Hayes (1984) emphasizes the importance of voicing assimilation as a great impediment for efficient pronunciation. According to Slis (1986), assimilation of voice comes into being in Dutch as a function of stress, word boundaries, and the sex of speaker and listener. Moreover, Rubach (1996) insists that non-syllabic analysis of voice assimilation in Polish is a case of serious assimilatory problem for the non-native learners of Polish. Moreover, Rubach (1997) additionally attaches the Polish voice assimilation in relation to Optimality Theory. Barry (1988) and Burton and Robblee (1999) argue the assimilation problems in relation to pronunciation difficulty in fast speech in Russian. Similarly, Iverson and Salmons (1995) mark assimilation as a hardship of articulation in German. Moreover, Helgason and Ringen (2008) show that assimilation is a serious pronunciation deficiency causer in Swedish. Beckman, Jessen, and Ringen (2009) denote that assimilation in sounds is a grave problem that impedes good pronunciation in German phonology. Dmitrieva, Jongman, and Sereno (2010) stress the types of phonological neutralization in the speech of native and non-native speakers in connection the case of Russian final devoicing. Also, Ndung'u (2013) claims that the attainment of auditory perception and production of intelligible pronunciation patterns particularly in voicing, stress, rhythm and intonation are problematic to students of English in Kenya, which lead them to deviant unintelligible pronunciation structures and pronunciation fossilization. As a justification of this research, it can be stated that assimilation is a universal process in the languages of the world, but the ways it works via secondary articulation and coarticulation is language specific to some extent. That's why it must be analyzed in foreign language learning and the teaching process and taught to the students. In addition, whether these teachers require remedial assistance to achieve perception of assimilation in words created by co-articulation and secondary articulations or not can also be taken into consideration. 


\section{Theoretical Background}

Several approaches and theories take part in the explanation of assimilation in relation to pronunciation, co-articulation, and secondary articulations. It must be noted that phonology is a source of information for all these theories of speech communication and sound changes. For example, the General Auditory Approach shows the very beginning of co-articulation and secondary articulation activities that pave the way for assimilations in connected speech wherein. In this approach, "listeners perceive the acoustic signal itself rather than speakers' vocal tract gestures. Speech perception, according to this view, is served by domain-general auditory processes and perceptual learning mechanisms that have evolved to perceive relevant environmental sounds" (Viswanathan, Magnuson, \& Fowler, 2010, p. 1627).

In the Phoneme Theory, the phoneme (segment) is the smallest unit of phonology that explain the features and functions of phonemes. The Distinct Features Theory, on the other hand, explores phonetic features of sounds and phonemes over each other. In addition, Motor Theory of Speech perception argues that listeners are able to reconstruct messages from the process of smearing by reference to their own speech production in relation to_sound changes. It is this theory that monitors the perception of articulations as secondary or co-articulations in pronunciation incidents. The Feature Theory, on the other hand, can straightforwardly capture secondary articulations, such as labialization, aspiration, palatalization, labiovelarization, pharyngealization, and glottalization.

According to Crystal (2008, p. 35), "articulator-based feature theory in phonology is a development of feature theory in which speech is modeled in terms of a series of independently functioning articulators (lips, tongue front, tongue body, tongue root, soft palate, larynx), represented by nodes on separate tiers. Articulator features are also called 'place' features, because they are grouped under the place constituent in the feature hierarchy." Again, according to Crystal (2008, p. 35), "Articulator Model is a theory which aims to integrate phonetics and phonology into a single model, providing a feature analysis related to the muscular activity underlying the movements of individual articulating organs." Moreover, Locus Theory attempts to specify the place where something is situated or occurs. Diehl, Lotto, and Holt (2004, p. 154) write that "In contrast to MT [Motor Theory] and DRT [Direct Realist Theory], GA [the General Auditory framework] assumes that listeners' recovery of spoken messages from the acoustic signal (whether these messages are construed as distinctive features, phonemes, words, or some higher level linguistic units) is neither equivalent to nor mediated by the perception of gestures."

Each of the theories discussed here has putative advantages (Smith, 2010, p. 47) to explain the domains of pronunciation-related co/secondary articulations. In fact, each theory stresses the fact that assimilation in essence is a manifestation and developer 
of new allophones for pronunciation. It must be noted that in the field of foreign language education, many core sounds in relation to the target languages are cases of fossilized coarticulation and secondary articulations in pronunciation. So the objective of this research is to diagnose and rehabilitate these fossilized articulations to achieve an intelligible and accurate pronunciation and intonation in non-native prospective Turkish teachers of English.

\section{Research Objectives}

By taking into account the related literature and theoretical background mentioned so far, this study tries to deal with the following research questions.

1. Do the participants have serious recognition problems with sound assimilations created by co-articulation and secondary articulation in the perception of assimilation in words?

2. Is there a significant difference between females and males in terms of recognition problems?

3. Do these teachers require remedial assistance to achieve perception of assimilation in words created by co-articulation and secondary articulations?

\section{Method}

This study aims to explore pre-service English teachers' perception hardships that come into being during the sound assimilations developed via co-articulation and secondary articulation in the structure of connected speech in English utterances and to find out the extent to which a remedial treatment would help them overcome those difficulties. This study is based on a group a pretest and posttest research design.

\section{The Participants}

To explore the perceptibility level of the co-articulatory phenomenon in English by Turkish students, a pretest of 25 questions on the perception of assimilation was administrated to 38 freshmen Turkish teaching students training in EFL instruction, at Hacettepe University in the Department of English Language Education; among the participants there were no students who had lessons in the prep school: the participants established a homogenous group. They are selected on purposeful voluntary basis. The participants were Turkish freshmen foreign language teaching students, at Hacettepe University in the Department of English Language Education. They are selected on purposeful voluntary basis. The participants in the department are in the first year of their professional education, which will make them professional English language teachers three years later in Turkey. 
The profile of the participants is as follows:

\begin{tabular}{|c|c|c|c|}
\hline \multicolumn{4}{|c|}{$\begin{array}{l}\text { Table } 1 \\
\text { The Profile of the Participants }\end{array}$} \\
\hline Participants & & Count & Table N \% \\
\hline \multirow{2}{*}{ Gender } & Female & 22 & $57.9 \%$ \\
\hline & Male & 16 & $42.1 \%$ \\
\hline \multirow{3}{*}{ Age } & 18 & 20 & $52.6 \%$ \\
\hline & 19 & 14 & $36.8 \%$ \\
\hline & $20+$ & 4 & $10.5 \%$ \\
\hline TOTAL N & 38 & & \\
\hline
\end{tabular}

The participants had previously studied, in a survey basis, assimilation in to relation coarticulation and secondary articulation in connected speech, in dialogues and partially in interviews in terms of recognition level.

\section{Measuring Instruments}

Pretest procedures. This research is based on one group design only. The participants took one term a course on phonetic transcription in a course titled İÖ 175 Listening and Articulation II in which they learned and practiced all types of phonetic transcriptions. But the students took the tests in normal written English, as seen in the appendix. Transcription is just used to denote the internal structures of sounds and phonemes of words, phrases and clauses in connected speech. In addition, sentences and short dialogues were used as samples for exercises, taken from speaking Longman Dictionary of Contemporary English (2009) and Longman Dictionary of American English (2008) with CDROM.

The highest score that can be obtained in the pretest is 25 . The points from 0 to 10 indicate low-achievers, points from 11 to 19 denote mid-achievers, and points from 20 to 25 indicate high achievers. At the end of the study, the pretest takers obtain a mean of 9.6579 (Table 2) which simply implies that the participants had problems in co-articulation and secondary articulation in the structure of connected speech in English utterances as predicted by the researcher prior to the study.

The pretest and the posttests were designed by the researcher. The two tests were examined and evaluated by three experts in relation to validity, and then they were applied to the participants.

Students took a multiple-choice pretest that included 25 questions. SPSS 20 was used to evaluate the statistical changes. Each question in the tests was given a score of 1 if correct, and zero if the answer is incorrect. After administrating the pretest, the following measurements were reached in form of paired samples statistics as a case of $t$-test: 
Table 2

The Results of the Pretest; Paired Samples t-test

Paired Samples Statistics

\begin{tabular}{lccccc}
\hline & & Mean & $N$ & Std. Deviation & Std. Error Mean \\
\hline Pair 1 & Pretest & 9.6579 & 38 & 2.12166 & .34418 \\
\hline
\end{tabular}

A careful analysis of Table 2 simply indicates that the participants of the study had problems in coarticulation and secondary articulation in connected speech $(M=9.6579)$.

Posttest procedures. A three-hour intensive remedial teaching process took place. Since the mean score of the pretest was 9.6579 (they were able to answer around 10 questions out of 25 questions), the first research question was proven to be accurately predicted by the researcher. A three-hour intensive remedial teaching process then took place. The related words, phrases, and clauses, and sentences that were used in the exercises were downloaded from Longman Dictionary of Contemporary English (2009) and Longman Dictionary of American English (2008). The related words, phrases, and tongue twisters were downloaded with Audacity 1.2.6 in .wav form in audio track mono at $44100 \mathrm{~Hz}$ in 32-bit float. All of the texts, including the dialogues and short interviews, were presented in audio form, which were very distinctly recorded and presented to the students in class.

The following practice types were exercised in class:

EXAMPLE PRACTICE STUDIES: Assimilation as a promoter of co-articulation

After administration of the pretest to the students, the following explanations the participants were repeated again in the course of study. The revision of the formerly studied texts and some of the exercises took place in form of a lecture, oral practices, mentioned in the appendix and some more exercises subtracted from the related two electronic speaking dictionaries, were made in the soundproof language lab.

Explanations. (It must be noted that the following explanations were given to the participants as a PowerPoint after example practice studies in class finished.) According to Crystal $(2008$, p. 39) assimilation refers to "a general term in phonetics which refers to the influence exercised by one sound segment upon the articulation of another, so that the sounds become more alike or identical". If the sounds become completely the same, it is called total assimilation; if partly similar, the result is called partial assimilation. It must be noted here that assimilation is the physical ground for the establishment of coarticulations. Assimilation incident can be classified according to the direction in which the assimilation works. There are three options in this respect:

A regressive (or anticipatory) assimilation the sound adjust itself in accordance with the attraction of the following sound: 
The affixation of the prefix $\{$ in- $\}$, borrowed from Latin to English exhibits this type of assimilation. Similarly, \{en- $\}$ and $\{$ con- $\}$ demonstrate almost the same processes of assimilation. The bilabial phonemes like /p, b, m, w/ magnetically change the /n/ of $\{$ in- $\}$ into [m] via regressive assimilation. This is a manner of articulation change that creates a new allophone for the $/ \mathrm{n} /$ phoneme.

In the foregoing transcriptions / '/ stands for primary stress phoneme, /, / stands for secondary stress phoneme, and / $\mathrm{x} /$ stands for retroflex flap in North American English (NAE).

\begin{tabular}{|c|c|}
\hline Vocabulary & Assimilation in Orthography \\
\hline in + pact & impact \\
\hline in + practical & impractical \\
\hline in + mune & immune \\
\hline in + mortal & immortal \\
\hline in + modest & immodest \\
\hline in+balance & imbalance \\
\hline in + polite & impolite \\
\hline in + pose & impose \\
\hline$\underline{\text { Vocabulary }}$ & Assimilation (Velar Assimilation) \\
\hline in + crease & increase /ı' kni:s/ \\
\hline in + correct & incorrect/,Inkə'...ckt/ \\
\hline in + complete & incomplete /, Inkəm' pli:t/ \\
\hline in + cubation & incubation/'inkjə, beiðən/ \\
\hline in+gratiate & ingratiate /In' g.eI $[\mathrm{i}$, ert/ \\
\hline in+grained & ingrained /In' g.eind/ \\
\hline in + gratitude & ingratitude /In' g.ææDə,tu:d/ \\
\hline
\end{tabular}

Assimilation in

Pronunciation

input ['Impot]

inpatient ['Im, peI_ənt]

in-between ['Im, bitwi:n]

inbred [, Im'bıcd]

inborn [, Im'bo..n]

inwards ['Imwə.Idz]

inwardly ['Imwə.Idli]

inward ['Imwərd] 


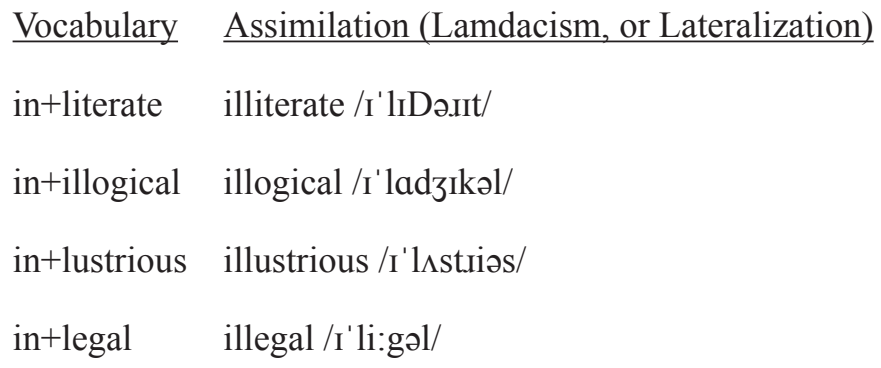

Vocabulary Assimilation (Rhotacism)

in+regular irregular/I'..egjələx/

in+repairable irreparable /ı'ıєрә.əbəl/

in+relevant irrelevant/I'JEləvənt/

in+resistible irresistible /, ,uı'zistəbəl/

A: The rules of regressive assimilation, which creates several allophones, can be formulated as follows: the / I / sound stands for a retroflex flap in North American English (NAE).

1. $/ \mathrm{n} / \rightarrow[\mathrm{m}] /---\{\mathrm{p}, \mathrm{b}, \mathrm{m}, \mathrm{w}\}$

2. $/ \mathrm{n} / \rightarrow[\mathrm{y}] /---\{\mathrm{k}, \mathrm{g}\}$

3. $/ \mathrm{n} / \rightarrow[1] /---1$

4. $/ \mathrm{n} / \rightarrow[\mathrm{I}] /--\mathrm{I}$

B: Progressive assimilation the sound changes because of the influence of the preceding sound, which functions as the conditioner, but such an assimilation is less common.

An example from Turkish:

$\underline{\text { Standard Turkish }}$

Dinlediniz mi?

$(\mathrm{Did}+\mathrm{you}+$ listen + to $+\mathrm{it})$

Anlamadım.

$(\mathrm{I}+\mathrm{did}+$ not + understand $)$

\section{$\underline{\text { Colloquial Turkish }}$}

[dinlediniz $+\mathrm{mI}]$

[dinnediniz $+\mathrm{mI}]$

[annamadim] 


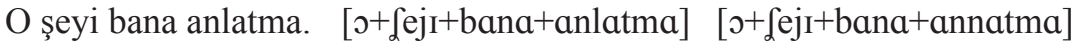

(Don't+tell+me+that+thing)

(Demirezen, 1986, p. 37)

C: Coalescent (or reciprocal) assimilation denotess a mutual influence, or union, of the sounds upon each other, as when don't you is pronounced as [dount [u:] and did you as [didzju:], where the letters $\boldsymbol{t}$ and the $\boldsymbol{y}$ have merged to produce affricates like [t]] and [dz] in the colloquial forms.

\section{Formal}

Don't you like it?

[dount+ju:+lark+It]

Didn't you drink it?

[didnt+ju:+d.ınk + It $]$

Wouldn't you be happy?

Did you tell them?

Could you bring it? [wodnt+ju:+bi:+hæpi]

[did+ju:+tel+ðəm]

[kod+ju:+b.ıng $+\mathrm{It}]$

\section{$\underline{\text { Colloquial }}$}

[doont_u:+lark+It]

[didnt/u:+d.ınk+It]

[wodnt_u:+bi:+hæpi]

[didz+tzl+ðəm]

[kudzu:+b.ing+It]

The /f/ and /v/ phonemes of English, when encountering the $/ \mathrm{n} /$ or $/ \mathrm{m} /$ phonemes across morpheme boundaries, undergo a coalescent assimilatory process in the following manner; the assimilating phoneme is $/ \mathrm{m} /$ and the assimilated phoneme is /f/, which is a voiceless labio-dental fricative.

\begin{tabular}{|c|c|c|}
\hline Vocabulary & Bilabilization & $\underline{\text { Labio-dentalization }}$ \\
\hline comfort['kımfə.tt] $\rightarrow$ & ['kımфә.tt] $\rightarrow$ & ['k^mффә.t] \\
\hline comfy ['kımfi] & {$[$ 'k $\wedge \mathrm{m} \phi \mathrm{i}] \quad \rightarrow$} & ['k^mథi] \\
\hline
\end{tabular}

In the above-mentioned examples, $/ \mathrm{f} /$, being a voiceless labio-dental fricative before, shifts into a voiceless bilabial fricative at the end, where this is a change of place of articulation. 


\section{$\underline{\text { Vocabulary }}$ Bilabialization $\rightarrow$ Bilabialization $\rightarrow$ Labio-dentalization \\ convene $\left[k^{\prime} n^{\prime} v i: n\right] \rightarrow \quad\left[k^{\prime} m^{\prime} v i: n\right] \rightarrow \quad\left[k^{\prime} m^{\prime} \beta i: n\right] \rightarrow\left[k ə m^{\prime} \beta i: n\right]$

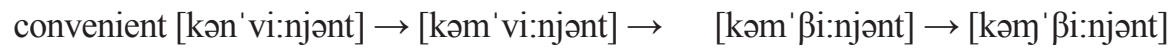

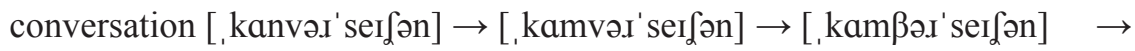

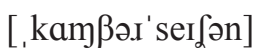

In the examples given above, the $/ \mathrm{mf} /$ consonant cluster shifts into [m $\phi]$ by means of a bilabial assimilation of an /f/ that was a labio-dental fricative in the first phase of the change. Subsequently, $[\mathrm{m} \phi]$ consonant cluster shift into $[\mathrm{m} \phi]$ by the magnetic pull power $[\phi]$, and the result is the converse of [m] into [m], which is a labio-dental nasal sound, all coming down to [m $\phi]$, that shows the occurrences of a coalescent (or reciprocal) assimilation.

Similarly, the /nv/ consonant cluster in a word firstly changes to [mv] through a labio-dentalization, which in turn by the influence of [m], the voiced labio-dental sound, is converted into $[\mathrm{m} \beta]$, exhibiting the bilabial assimilation of a labio-dental fricative. Ultimately, the result is a phonetic change of initially being /nv/, consonant cluster that shifts into $[\mathrm{m} \beta]$; demonstrating a phonetic occurrence of a coalescent (or reciprocal) consonantal assimilation, whose phonetic rule can be formulated as follows:
1. /f, v/ $\rightarrow[\phi, \beta] /----+m$
A bilabial assimilation of labio-dental sounds

2. $/ \mathrm{n}, \mathrm{m} / \rightarrow[\mathrm{m}] /$---- $+\{\phi, \beta\}$

A labio-dental assimilation of alveolar and bilabial nasal sounds

All types of assimilations are the physical basis for the establishment of coarticulations and secondary articulations. In coalescent (or reciprocal) assimilation, regressive (or anticipatory) assimilation and progressive assimilation (or perseveratory) assimilations can take place conjointly. For a remedial teaching process, the following issues can be clearly explained to the students before giving them a final text material.

\section{Types of co-articulation}

From the outset it must be borne in mind that co-articulation is a case of assimilation, namely the assimilation of the place of articulation of a phoneme to that of an adjacent phoneme. There are three basic types of co-articulation: progressive co-articulation (perseverative or perseveratory), which is created by progressive assimilation, regressive (or anticipatory) co-articulation, developed by regressive assimilation, and coalescent (or reciprocal) co-articulation. 
A. In a "progressive" (perseverative or perseveratory) "co-articulation," which is otherwise called progressive assimilation, a "sound retains a characteristic deriving from an earlier articulation, as when the [n] in seen is articulated slightly further forward than the $[\mathrm{n}]$ in soon. Alternative terms include right-to-left (for anticipatory) and left-to-right (for perseverative)" co-articulation (Crystal, 2008, p. 82). In the perseverative coarticulation, the effects of a sound are seen during the production of sound(s) that follow. In other words, in progressive or preservative type of assimilation, "the conditioning sound precedes and affects the following sound" (Celce-Murcia, Brinton, \& Goodwin, 2007, p. 160).

Apart from the typological similarities of the target and mother tongue, the numbers of consonants, vowels or semi-vowels are influential on the occurrence of co-articulations. For example, when a language has a small vowel inventory, it seems to allow greater co-articulation (Manuel, 1987; Manuel \& Krakow, 1984). In this respect, the English language with 13 vowel phonemes will naturally cause problems to Turkish learners of English, because it has eight vowels viz. /i, e. ü, ö ,i a, u, o/.

B. In "regressive" (or anticipatory) "co-articulations," two articulations coincidentally take place in the same vocal tract. The extent to which anticipatory coarticulation occurs depends on the extent to which the position of that party of the tract is specified in the two targets (Ladefoged, 2009, p. 69). In regressive (or anticipatory) co-articulation, the assimilated sound precedes and is affected by the conditioning sound. The assimilated sound comes before the conditioning sound. In this type of coarticulation, then, an articulator begins to travel in the direction of an articulation needed for a later sound in the utterance. An example is "the sh- of shoe, which is normally pronounced with lip-rounding, anticipating the influence of the following articulations" (Crystal, 2008, p. 82). Therefore, in a regressive coarticulation a phonetic feature of a speech sound is estimated in connection to the production of a preceding speech sound. In English, regressive assimilation is more pervasive and purely phonological than is progressive assimilation (Celce-Murcia et al., 2007, p. 160).

C: Coalescent (or reciprocal) co-articulation. There is a mutual influence, or blending, of the sounds upon each other, as when won't you is pronounced as [wount/ju:] and how about you as [hav ə'baut/ju:]: in such phrases, the $t$ and the $y$ have mixed to produce an affricate like [t/] in the colloquial forms. 


\section{Formal}

Didn't you drink it?

$$
[\mathrm{d} \text { Idnt+ju:+d.ıIj }+\mathrm{It}]
$$

Wouldn't you be happy?

Did you tell them?

Could you bring it? [wodnt+ju:+bi:+hæpi]

$$
\text { [dId+ju:+tel+ðəm] }
$$

[kvd+ju:+b.ıng+rt $]$

\section{$\underline{\text { Colloquial }}$}

[didnt $\mathrm{u}:+\mathrm{d} . \mathrm{I} \mathrm{j} \mathrm{k}+\mathrm{It}$ ]

[wodnt/u:+bi:+hæpi]

[dIdzu:+tعl+ðəm]

[kudzu:+b.ıng+It]

Examples of coarticulations: In the production of a co-articulated consonant, that consonant is articulated with two simultaneous places of articulations. Most common examples of coarticulations are assimilation, aspiration, dentalization, nasalization, and rounding.

The following examples exhibit the cases of regressive (or anticipatory) coarticulation. All of these examples are downloaded with Audacity from the electronic dictionary Contemporary American English (2004), published by Longman. The sign for dentalization is [ $\mathrm{s}$, which is placed underneath the dentalized consonant, is called tilde:

\begin{tabular}{|c|c|c|}
\hline$\underline{\text { Single articulation }}$ & $\underline{\text { Co-articulation I }}$ & $\underline{\text { Co-articulation II }}$ \\
\hline deep [di:p] & $\operatorname{deep}[\mathrm{d} \varepsilon \mathbf{p} \theta]$ & esthetic $\left[\varepsilon \mathbf{S}^{\prime} \theta \varepsilon \mathrm{DIk}\right]$ \\
\hline toot [tu:t] & tooth $[\operatorname{tu}: \theta]$ & dearth $[\mathrm{d} 3: \mathrm{I} \theta]$ \\
\hline ten $[\mathrm{t} \varepsilon n]$ & tenth $[\operatorname{ten} \theta]$ & thirteenth $\left[, \theta 3:\right.$ I $^{\prime}$ ti:n $\left.\theta\right]$ \\
\hline boot [bu:t] & booth [bu: $\theta]$ & 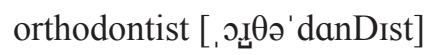 \\
\hline pat [pæt] & path [pæ $\theta]$ & something ['s $\Lambda \mathbf{m} \theta \mathrm{I} \mathrm{I}]$ \\
\hline mat [mæt/ & math [mæ$\theta]$ & although [ol'ðov] \\
\hline nine [nain] & nineth [nain $\theta$ ] & breadth [b.ıd $\mathbf{d} \theta$, b.ıct $\theta]$ \\
\hline seven [scvən] & 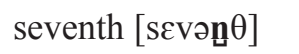 & arthritic [a $a_{\lrcorner}^{\prime} \theta_{\text {IIIDIk }}$ \\
\hline grow [g.ıov] & growth [g.⿲o丨 $\theta$ ] & panther ['pæn $\theta \partial x]$ \\
\hline long [lon] & 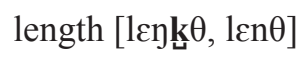 & 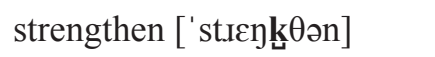 \\
\hline fart [fast] & farther [' faııðəI] & enthusiasm [In ' $\theta$ u:zi: „æzəm] \\
\hline
\end{tabular}

\section{Dentalization.}




\section{Tongue Twisters:}

All of the tongue twisters given in the following pages can be practiced in class. The text is downloaded from text to speech labs in native-speaker's audio form via Audacity, and practiced as single or choir articulations and repetitions.

(a) The seventh

The seventh and the ninth

The seventh and ninth and the tenth

The seventh and ninth and the tenth of the orthodontists

(b) The strength

The strength and breadth

The strength and breadth and enthusiasm

The strength and breadth and enthusiasm of the panther

In the words given above, the word-final $/ \mathrm{n} /$ of the above-mentioned words is pronounced with an alveo-dental place of articulation because the sound $/ \theta /$, which has an inter-dental place of articulation. The cause of this co-occurrence is a completely environmental effect with two simultaneous places of articulation that occur upon each other in a case of co-articulation.

\section{Nasalization as a secondary articulation}

All vowels become nasalized when followed or preceded by a $/ \mathrm{m}, \mathrm{n}, \mathrm{y} /$. In phonetics, "nasalization" involves the production of a sound while the velum is lowered, such that some air manages to escape through the nose (nasal cavity) during the production of the sound by the mouth (oral cavity). In the IPA system, the symbol for nasalization is [ $\left.{ }^{\sim}\right]$, which is placed at the top its related vowel phoneme:

\begin{tabular}{|c|c|c|}
\hline belong [‘bilõn] & long [‘'1̃̃] & gang [_gæ̃y] \\
\hline song [_s̃̃y] & swing [_swĩy] & young $\left[{ }^{\circ} \mathrm{j} \tilde{\Lambda} \eta\right]$ \\
\hline wrong ['Jว̃ท] & ringing ['Ĩngyĩn] & ping pong [‘[ĩypõy] \\
\hline singsong [_[Ĩ̄sว̃y] & upbringing [' $\Lambda$ pb.IIngĩn] & slinging [‘'slĩngĩy] \\
\hline questioning ['kwest/כ̃nĩn] & bringing [b.Ĩngĩn] & King Kong ['Kĩn kõy] \\
\hline springing [sp.ĩngĩn] & singing [sĩngĩn] & 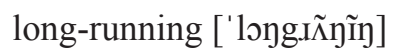 \\
\hline
\end{tabular}




\section{Tongue twisters:}

(b) Swinging

Swinging and slinging

Swinging and slinging of a gang

Swinging and slinging of a young gang a singsong (b) A questioning

A questioning of King Kong

A wrong questioning of King Kong

A wrong questioning of King Kong on

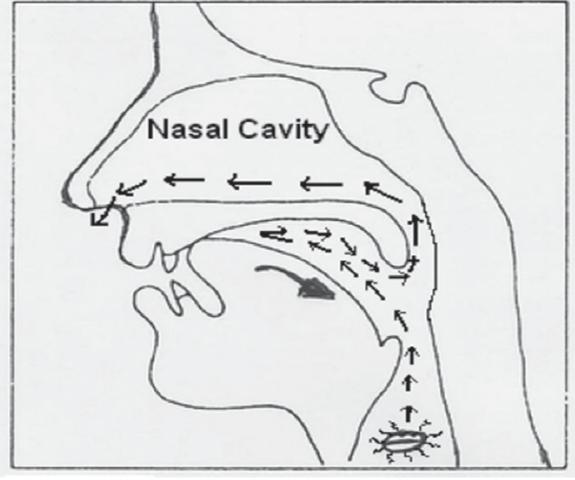

Articulation of $/ \mathbf{n} /$

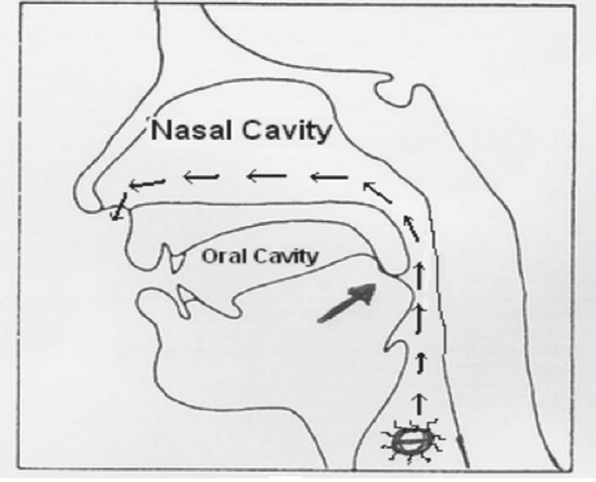

Articulation of $/ \mathrm{D} /$

Figure 1. The articulatory positioning of nasalisation in the nasal cavity.

There is potential benefit in studying the features of secondary articulation and co-articulation for the non-native teachers and students of English, because they are able to spread out articulatory and acoustic information about consonants, vowels, or semi-vowels, and help a listener to understand what is being said; in this way, they become a background for accuracy and intelligibility, ensuring that speech sounds are produced very smoothly and intelligibly.

\section{Dentalization and nasalization at the same time}

In the following words, a phonological neighborhood density arises and creates nasalisation more than once, because / $\mathrm{m}, \mathrm{n}, \mathrm{y} /$ phonemes or sounds exert a nasal feature onto the preceding vowels. It is quite possible that any of / m, n, $\mathrm{y} /$ can come more than

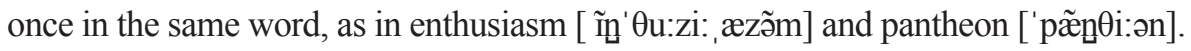




\begin{tabular}{|c|c|c|}
\hline Single articulation & $\underline{\text { Co-articulation I }}$ & $\underline{\text { Co-articulation II }}$ \\
\hline nine [nain] & nineth [nain $\theta]$ & nineth [naĩn $\theta]$ \\
\hline seven [sعvən] & seventh [sevən $\theta]$ & seventh [scvãn $\theta]$ \\
\hline long [loy] & length $[\operatorname{l\varepsilon \eta k} \theta]$ & 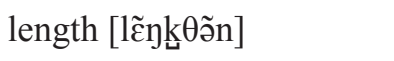 \\
\hline panther ['pænӨəI] & panther ['pænӨəı] & panther ['pæ̃nูӨə.I] \\
\hline $\operatorname{tent}[\operatorname{tent}]$ & tenth $[\operatorname{ten} \theta]$ & thirteenth [, $\theta 3: .{ }^{\prime}$ tĩ:n $\left.\theta\right]$ \\
\hline strengthen ['stı\&yk $\theta ə n$ ] & strengthen ['stı\&りk $\theta ə n]$ & 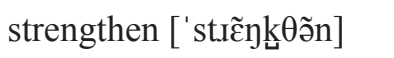 \\
\hline 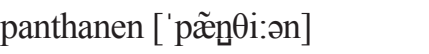 & panthanen['pænӨi:ən] & 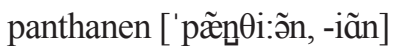 \\
\hline 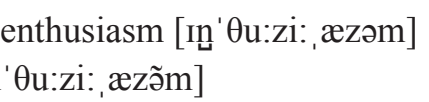 & enthusiasm [In' $\theta$ u:zi:æ & enthusiasm \\
\hline
\end{tabular}

Tongue Twisters: The following twisters, if used in small doses, can help to build the skills on secondary articulation at the word and phrase levels:

(a)The enthusiasm

The enthusiasm of the panther

The enthusiasm of the panther in the cathedral

The enthusiasm of the panther in the orthodox cathedral

(b)The ninth

The ninth and tenth

The ninth and tenth and eleventh

The ninth and tenth and eleventh month

\section{Secondary articulation and co-articulation in the same words as multiple articulations}

Coarticulation is the acoustic and articulatory similarity that comes into being when the articulations of neighboring segments cover one another. In the event of an overlap, due to the density of neighborhood, secondary articulations can arise, such as palatalization, labialization, rounding, flapping, velarization, labio-velarization, aspiration, glottalisation, syllabic consonant formation (dark-1 and clear-1 formations), lip-rounding (Roach, 2009). Therefore, in the same utterance of a word or multiple words, there may be both a secondary articulation and a co-articulation taking place 
side by side. In the following words or phrases, bidirectional co-articulation, which indicates the simultaneous occurrence of progressive or regressive co-articulations and secondary articulations, are given:

Labialization and flapping.

$[w]$ stands for labialization and $[D]$ for flapping

a)quality ['kwaləDi] $\quad$ b) equilateral [i:kwə'læDə.əl]

tranquility [træn'kwıləDi] twitter ['twıDər]

equitable ['ekwəDəbəl] equality [I'kwaləDi]

A tongue twister:

Equilateral

Equilateral tranquility

Equilateral and equitable tranquility

Equilateral and equitable tranquility in equality

Labialisation and glottalisation.

acquaintance [ə'kwein?ns]

Palatalization and flapping.

unity ['ju:nəDi]

mutable ['mju:Dəbəl]

utility [ju:'trləDi]

uterus ['ju:Də.əs]

\section{A Tongue Twister:}

The unity

The unity and utility

The unity and utility of university

The unity and utility in the universality of the university

$$
\begin{aligned}
& \text { unanimity [ju:næ'nıməDi] } \\
& \text { jocularity [dzakjə' læ.əəDi] } \\
& \text { mutuality [mju:t\{u:'æləDi] } \\
& \text { university [,ju:nə' v3:IsəDi] }
\end{aligned}
$$


Palatalization and a syllabic consonant.

tribunal [tıa' bju: ņl, t.ıI-] communal [kə' mju: ņl]

Glottalization and a syllabic consonant.

\begin{tabular}{|c|c|c|}
\hline cotton ['ka?n] & Latin ['læ?ñ] & unbutton $\left[\Lambda \mathrm{n}^{\prime} \mathrm{b} \Lambda \mathrm{P} n\right]$ \\
\hline mutton ['m $\mathrm{m}$ ?n] & written [' II?n]] & unbeaten $\left[\Lambda \mathrm{n}^{\prime} \mathrm{bi}: ?\right.$ \\
\hline beaten ['bi:?n]] & lighten ['lai?n] & shorten [' ЮuPn,] \\
\hline
\end{tabular}

Tongue Twisters:
(a) A cotton
b) shorten

A cotton button

shorten and lighten

A cotton button written

shorten and lighten the mutton

A cotton button written in Latin

shorten and lighten the beaten mutton

Flapping and syllabic consonant

fatal ['ferDl]

instrumental [Instıə' menD1]

fetal ['fi:Dl]

immortal [I'mə.əəD!̣]

fertile [' fə..D!̣]

kettle ['keDl]

chortle ['t $[\mathrm{J} . \mathrm{D} 1]$

digital ['dıdzIDl]

A Tongue Twister:

A digital

A digital and instrumental

A digital and instrumental kettle

A fatal, digital and instrumental kettle

Palatalization, labialization, and flapping.

ubiquitous [ju:'bıkwəDəs] ubiquity [ju:'bıkwəDi]

Labialization, flapping and syllabic consonant

acquittal[ə'kwiDl] 
Two flappings, glottalization, and syllabic consonant

intercontinental [inDə.kkan?' nenD 1] or [inDə.xkantə' nenD!̣]

Two flappings and a syllabic consonant

interdepartmental [InDə.ıdıpa:It' meņD!̣]

Glottalization, a syllabic consonant and flapping

uncertainty [ $\Lambda \mathrm{n}^{\prime} \mathrm{s} 3: \mathrm{I}$ ?ņDi]

\section{Results}

In three hours of intense teaching and practice, as seen in the section of practice studies, assimilation came up as a great promoter of co-articulations. Several examples on assimilation and co-articulation were studied about 7 pages that were given in the example practice studies of this article. The same participants, after two weeks, were given a posttest whose 25 questions were new. They were not studied before. The participants had not encountered them in the practice studies. This way, the possibilities of remembrance of the pretest items were removed from the context.

After the application of the posttest, the paired sample statistics came up to be like this:

Table 3

Pretest and Posttest Results in Form of Paired Samples Statistics

\begin{tabular}{llcccc}
\hline & & Mean & N & Std. Deviation & Std. Error Mean \\
\hline \multirow{2}{*}{ Pair 1 } & Pretest & 9.65 & 38 & 2.12 & .34 \\
& Posttest & 19.16 & 38 & 1.92 & .31 \\
\hline
\end{tabular}

As seen in the appendix, the posttest questions were new, which they did not take place in the pretest: the point here is that the impacts of memorizing or remembering of the test items were removed from the study. It is apparent that after taking the Pretest, the participants have improved their perception on the assimilation and its types and they have almost become almost high achievers. This case points to improvement in assimilation as co-articulation and secondary articulations and their distributions in English utterances.

\section{Evaluation of the Pretest and Posttest Results}

$R Q \# 1$ : Do the participants have serious recognition problems with the perception of assimilation in words?

In addition, in order to see if the participants have serious recognition problems with the perception of assimilation in words, a percentage study was utilized and the mean scores were taken into account for both the pre- and the post- tests. The mean, 
being 9.6579 as an outcome of the pretest, indicates that perception of assimilation by the participants is low because the participants got approximately a score of 10 correct answers out of 25 in answering the questions. After the administration of the posttest, the mean score changes from $9.6579(38,6316 \%)$ to $19.1579(76,6316 \%)$ and a meaningful difference, denoting the significant difference of the remedial treatment in terms of statistics.

$R Q$ \#2: Is there a significant difference between females and males in terms of recognition problems?

At it is seen in the paired samples test (Table 5), there is a significant difference between pretest and posttest in terms of gender, $(t=8.44$ for males; $t=7.36$ for females, Sig. .000), with males having higher mean scores both in pretest $(M=25.95, S D=4.50)$ and posttest $(\mathrm{M}=16.45, \mathrm{SD}=3.69)$ than females in pretest $(\mathrm{M}=22.40, \mathrm{SD}=4.45)$ and posttest $(\mathrm{M}=12.49, \mathrm{SD}=3.49)$, indicating that males have more problems in terms of recognition than females. In general, since the remedial treatment of three hours created success in the recognition of assimilations in relation to secondary articulation and co- articulation; the errors seem to be reduced, in both of the sexes.

\begin{tabular}{|c|c|c|c|c|c|}
\hline \multicolumn{6}{|c|}{$\begin{array}{l}\text { Table } 4 \\
\text { Descriptive Statistics for Pretest and Posttest }\end{array}$} \\
\hline Gender & & & Mean & $\mathrm{N}$ & Std. Deviation \\
\hline \multirow{2}{*}{ Male } & \multirow{2}{*}{ Pair 1} & Pretest & 25.95 & 22 & 4.50 \\
\hline & & Posttest & 16.45 & 22 & 3.69 \\
\hline \multirow{2}{*}{ Female } & \multirow{2}{*}{ Pair 1} & Pretest & 22.40 & 16 & 4.45 \\
\hline & & Posttest & 12.49 & 16 & 3.49 \\
\hline
\end{tabular}

Put differently, as seen in Table 4, the higher mean score in males indicates that they still have problems with perception of assimilation in words although the ability to recognize problematic sounds has been greatly improved in both groups through intervention. The interpretation of the results given in Table 4 could be that the lower the scores in the posttest for both groups simply show significant improvement recognition problems.

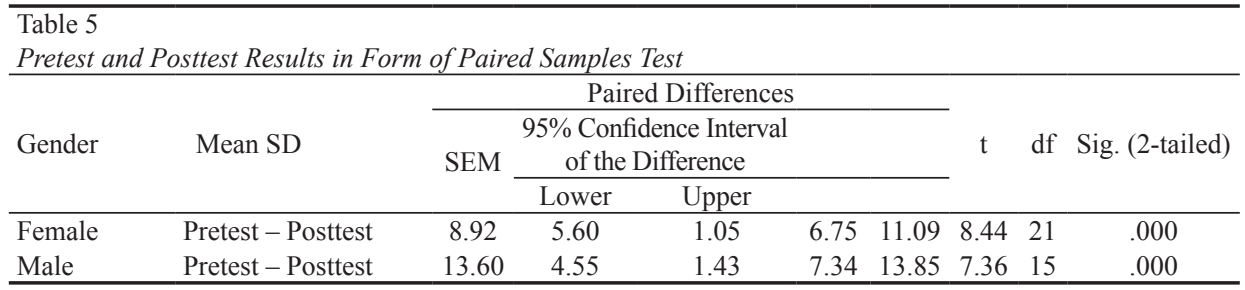

$R Q \#$ 3: Do they need a treatment on the achievement of the perception of assimilation in words? 
The mean of $9.6579(38,6316 \%)$ signals that the participants were seriously in need of treatment; the assimilation In Table 3 (Pretest and Posttest results in form of paired samples statistics), the mean score rises from 9,6579 (38,6316\%) to $19,1579(76,6316 \%)$, which points to the fact that treatment practice and teaching applications were successful, wherein there is a meaningful difference between the Pretest and Posttest results. In addition, the collective outcome of the research questions may mean that the three research questions were correctly presupposed and rightfully came true. Yet it cannot still be said that this change in the mean score will be satisfactory enough for an academic evaluation.

Then, the participants with a rate of $76,6316 \%$ success can be accepted as moderately satisfactory because this is the Department of English Language Education, requiring better success in the training of professional foreign language teachers; after the Posttest, the participants' success developed from 9, 6579 (38, $6316 \%)$ to $19,1579(\% 76,6316 \%)$, as denoted in table 3 , which shows that they have become high achievers. Therefore, they definitely don't need some more hours of treatment in this respect.

\section{Conclusions and Pedagogical Implications}

It is apparent that, assimilation as a promoter or catalyst of co-articulation and secondary articulation, is a serious problem for Turkish students of English Language Education, as the result of the first research question indicates, the mean was discovered as $9.5679(38,6316 \%)$. To answer to the question "what is the effect of short term remedial treatment" is that this problem is curable up to $19,1579(\% 76$, $6316 \%$ ) after a three hours of treatment. As the finding in the first research question in indicates, the rise of "metaphonological awareness" in the perception of the students in connected speech is a must. The finding in the third research question denotes that some hours of treatment are very beneficial to the participants, but still 76,6316\% success rate is not very good enough for them (Alseweed, 2012) because they will be professional English language teachers. So they may need some more hours of remedial teaching on assimilation that comes to the stage intertwined with coarticulation and secondary articulations in connected speech. This must be partially due to the fact that coarticulation and secondary articulations are physically allophone producing batteries for assimilation processes, many of which beguile the prospective Turkish students. But still the final success of the participants is moderately satisfactory.

The coarticulation, namely the perception of controlled acoustic variables by human brains, is a crucial issue when it comes to human speech behavior (Carr, 2008; Manuel, 1987). It refers to an articulatory situation in which an isolated 
phoneme is influenced by a preceding or following phoneme and becomes more like it. Since all languages inevitably exhibit secondary articulation and co-articulation in their phonetic and phonological structures, they are considered to be universal characteristics of speech production. When they jointly arise in the same vocabulary items, a multi-articulation situation comes into being. Such words are abundant in English lexicon. In addition, in pronunciation, modifications brought by secondary articulation and coarticulation cooperation in speech have bidirectional characteristics that may cause perception confusions for non-native learners. Furthermore, when the pronunciation complications created by the L1 intermingle with those of the L2, the learners without a proper background are confounded by their interlingual phonology. The result is the formation of fossilized pronunciation errors, whose causes are attributed to secondary articulation and co-articulation cooperation.

In foreign language teaching, secondary articulation and co-articulation must be studied with careful attention, because they must be largely and automatically internalized so that they can be used in on-coming articulations in new speech situations. Practice on assimilation in relation to co-articulations and secondary articulations can promote the perception of colloquial or connected speech of non-native learners of English. Studies on the consonant clusters in relation to coarticulation can additionally improve the allophonic changes that take place in fluent speech, which the majority of EFL teacher trainees find challenging, along with nonnative teachers of English. Assimilation is an allophone producing machine, and each allophone is used in a specific phonetic context and may be involved in the phonological process, in addition to personal articulation habits or preference, which may indeed pose serious difficulties to listeners.

Assimilation in words, phrases, clauses and sentences are definitely a potential producer and trigger of magnetic impacts in speech by means of progressive and regressive assimilation forms in coarticulation and secondary articulation. Needless to say, articulation of individual sound segments is almost always influenced by the articulation of neighboring segments that besmear the segment in question, and often lead the speech process to the point of considerable overlapping of co-articulatory and secondary articulatory activities. It must be noted that the perception and production of primary and secondary articulation and co-articulations necessitate a metaphonological awareness, because they are in assimilation with highly complex productions in pronunciation. Teaching pronunciation is a far more sophisticated process than writing, in which the auditory input is supported by input from other sensory modalities. In this respect, "without a multisensory approach coupled with cognitive orientation, it is extremely difficult to teach pronunciation to adult learners of L2/FL" (Odisho, 2007, p. 27). The best technique is to keep a journal of all pronunciation errors created by assimilation in connected speech, and then undertake remedial practices to correct them. 


\section{Pedagogical Implications}

The results of this study have important pedagogical implications for non-native English language teachers, particularly in the area of pronunciation efficiency in relation to recognition of assimilation developed by secondary articulation and coarticulation, which is mainly based on the recognition and production of a metaphonological background of utterances in connected speech. As the participants indicated in interviews, the use of audio forms of the exercise materials from the voices of the native speakers were found to be extremely useful. The use of voices of the native speakers was reported to have given participants "metaphonological" awareness over the practiced materials in class. If the teacher himself/herself is unable to give good L2 input to students during teaching practice, this is highly likely to influence their perception of and attitudes towards the teaching profession. "Where teachers" own L2 knowledge is not at standard English level, the inadequacies of their own use of English is transferred to the learners whom they teach" (Stander, 2001, pp. 108-110).

One pedagogical implication of this is that assimilation, if not paid due attention, spoils pronunciation. This is understood from the low success of the participants in the pretest, as indicated in the first research question. Another pedagogical implication is that, as the statistics demonstrate in the posttest, assimilation is learnable, and when it is learned, it promotes accurate articulation, leading the abilities to at least near native-like speech. Another implication is that the students and teacher must first be convinced that pronunciation is something worth working on for the purposes of professionalization. They cannot choose an attitude in trying to sound minimally understandable to others as the teacher trainee in English teacher education departments; rather, they should try to sound really at least near native-like. It is a good idea for them to keep a journal or portfolio of all pronunciation errors caused by assimilation in connected speech.

Another pedagogical implication seen in this research is that, even though Turkey started to put up the beginning age of foreign language learning in 2013 as 4+4+4+ policy, the teaching of English in the counties of the world begins at primary schools today: the neurolinguistically-based concept is the earlier the better. In secondary, middle, and high schools, the teaching of English takes persistently its place in educational programs. At the higher education level, its value continues to grow. If a student's English is insufficient at this stage, it could result in crisis.

According to Nel and Müller (2010, p. 635), "the transition which English second language (ESL) students need to make when using English as language of learning in higher education is indeed a matter of great concern in the South African higher education sector". In addition, Chiwome and Tondlana (1992) and (Nel, \& Müller, 2010) have postulated that non-English speaking students whose mother-tongues are 
African languages prefer to be taught in English particularly at university, no matter if it takes longer to learn in the second language (L2) than in the mother tongue. Then, English as a lingua franca must be taught with due rigor at professional teacher training schools to prospective native or non-native teachers, who should attend other professional certificate courses after their graduation. Some of these courses are the Professional Certificate in English Language Teaching (PCELT), Teaching English to Speakers of Other Languages (TESOL) programs, ESOL (English as a second language) programs, Cambridge CELTA (Certificate of English Language Teaching to Adults), and the Certificate in TESOL (CertTESOL).

\section{References}

Alseweed M. A. (2012). University students' perceptions of the influence of native and nonnative teachers. English Language Teaching, 5(12), 42-52.

Barry, S. M. E. (1988). Temporal aspects of the devoicing of word-final obstruents in Russian. In J. N. Holmes \& W. A. Ainsworth (Eds.), Speech'88 - Proceedings of the Federation of Acoustical Societies of Europe (pp. 81-88). Edinburgh: Institute of Acoustics.

Beckman, J., Jessen, M., \& Ringen, C. O. (2009). German fricatives: Coda devoicing or positional faithfulness? Phonology, 26, 231-268.

Bester, G., \& Brand, L. (2013). The effect of technology on learner attention and achievement in the classroom. South African Journal of Education, 33, 1-15.

Birsh, J. R. (Ed.) (2011). Multisensory teaching of basic language skills (3rd ed.). Baltimore, MD: Brookes Publishing Company.

Burleig, P. (2011). A manual of English phonetics and phonology. Frankfurt: Gunter Narr Verlag.

Burton, M. W., \& Robblee, K. E. (1999). A phonetic analysis of voicing assimilation in Russian. Journal of Phonetics 25, 97-114.

Carr, P. (2008). A glossary of phonology. Edinburgh: Edinburgh University Press.

Celce-Murcia, M., Brinton, D.M. \& Goodwin, J. M. (2007). Teaching pronunciation: A reference for teachers of English to speakers of other languages. Cambridge: Cambridge University Press.

Chiwome, E., \& Thondhlana, J. (1992). Sociolinguistics and education: A survey concerning attitudes on the teaching of Shona through the media of Shona and English. In R. K. Herbert (Ed.), Language and society in Africa: Theory and practice of sociolinguistics (pp. 247263). Johannesburg: Witwatersrand University Press.

Collins, B., \& Meesi, I. M. (2013). Practical phonetics and phonology: A resource book for students. New York: Routledge.

Crystal, D. (2003). English as a global language. Cambridge: Cambridge University Press.

Crystal, D. (2008). A dictionary of linguistics and phonetics. London: Blackwell.

Demirezen, M. (1986). Phonemics and phonology: Theory through analysis. Ankara, Turkey: Bizim Büro Yayinlari.

Diehl, R. L., Lotto, A. J., \& Holt, L. L. (2004). Speech perception. Annual Review of Psychology, 55, $149-179$. 
Dmitrieva, O., Jongman, A., \& Sereno, J. (2010). Phonological neutralization by native and non-native speakers: The case of Russian final devoicing. Journal of Phonetics 38, 483-492.

Edwards, H. T. (2003). Applied phonetics: The sounds of American English. New York: Cengage Learning.

Farnetani, E. (1999). Co-articulation and connected speech processes. In W. J. Hardcastle\& J. Laver (Eds.), Handbook of phonetic sciences (pp. 371-404). Malden, MA: Blackwell Publishers.

Hardcastle, W. J., \& Hewlett, N. (2006). Coarticulation: Theory, data, and techniques. Cambridge: Cambridge University Press.

Hayes, B. (1984). The phonetics and phonology of Russian voicing assimilation. In M. Aronoff \& R. T. Oehrle (Eds.), Language, sound, structure (pp. 318-328). Cambridge, MA: The MIT Press.

Helgason, P., \& Ringen, C. O. (2008). Voicing and aspiration in Swedish stops. Journal of Phonetics 36, 607-628.

Iverson, G. K., \& Salmons, J. C. (1995). Aspiration and laryngeal representation in Germanic. Phonology, 12, 369-396.

Jansen, J. D. (2001). Imagining teachers: Policy images and teacher identity in South African classrooms. South African Journal of Education, 21, 242-246.

Jenkins, J. (2002). A sociolinguistically based, empirically researched pronunciation syllabus for English as an international language. Applied Linguistics, 23(1), 83-103.

Kachru, B. (1996). The paradigms of marginality. World Englishes, 15, 241-255.

Kavitskaja, D. (1999). Voicing assimilation and schizophrenic behavior of /v/ in Russian. In H. Coats, D. Katarzina, \& M. V. Cynthia (Eds.), Workshop on formal approaches to Slavic linguistics (pp. 225-244). Seattle, Wash.

Knight, R. A. (2012). Phonetics: A coursebook. Cambridge: Cambridge University Press,

Ladefoged, P. (2009). A course in phonetics (international student edition). Australia: Thomson Wardsworth.

Longman Dictionary of Contemporary English. (2009). Longman: Pearson.

Longman Dictionary of American English. (2008). Longman: Pearson.

Magen, H. (1984). Vowel-to-vowel co-articulation in English and Japanese. Journal of the Acoustical Society of America, 75, 541.

Manuel, S. Y. (1987). Acoustic and perceptual consequences of vowel-to vowel co-articulation in three Bantu languages (Doctoral dissertation). Yale University, New Haven.

Manuel, S. Y., \& Kralcow, R. A. (1984). Universal and language particular aspects of vowelto-vowel coarticulation.Haskins Laboratories, Status Report on Speech Research, 77, 69-78.

Medgyes, P. (1994). The non-native teacher. London: Macmillan.

Medgyes, P. (1999). The non-native teacher (Rev. 2nd ed.). Ismaning, Germany: Heuber Verlag.

Merino, I. G. (1997). Native English-speaking teachers versus non-native English-speaking teachers. Revista Alicantina de Estudios Ingleses 10, 69-79

Nel, N., \& Müller, H. (2010). The impact of teachers' limited English proficiency on English second language learners in South African schools, South African Journal of Education, 30, 635-650. 
Ndung'u, M. I. (2013). The teaching and learning of English pronunciation patterns and listening skills in Kenya. International Journal of Education and Research, 1, 1-20.

Odisho, E .Y. (2007). A multisensory, multicognitive approach to teaching pronunciation. Linguística - Revista de Estudos Linguísticos da Universidade do Porto, 2, 3-28.

Roach, P. (2009). English phonetics and phonology: A practical course. Cambridge: Cambridge University Press.

Rubach, J. (1996). Nonsyllabic analysis of voice assimilation in Polish. Linguistic Inquiry 27, 69-110.

Rubach, J. (1997). Polish voice assimilation in optimality theory. Rivista di linguistica 9, 291-342.

Slis, I. (1986). Assimilation of voice in Dutch as a function of stress, word boundaries, and sex of speaker and listener. Journal of Phonetics 14, 311-326.

Smith, N. (2010). Acquiring phonology: A cross-generational case-study. Cambridge: Cambridge University Press.

Stander, M. (2001). Taaloordrag in die onderrig van Afrikaans as tweedetaal. Literator, 22, 107-122.

Viswanathan, N., Magnuson, J.M.S., \& Fowler, C.A. (2010). Compensation for coarticulation: disentangling auditory and gestural theories of perception of coarticulatory Effects in Speech, Journal of Experimental Psychology, American Psychological Association Human Perception and Performance 2010, 36(4), 1005-1015.

\section{Appendix A}

\section{A Pretest on PHRASAL assimilation}

1. In which of the alternatives does the / $\mathrm{t} /$ phoneme can change into $[\mathrm{p}]$ ?
a) basket game
b) basket case
c) basket thrash
d) basket maker
e) basket acrobat

2. In which of the alternatives does the /d/ phoneme can change into $[\mathrm{b}]$ ?
a) bad pain
b) mad gain
c) sad aim
d) bad rain
e) lad labor

3 . In which of the alternatives does the $/ \mathrm{n} /$ phoneme can change into [m]?
a) common salary
b) common zone
c) Common Market
d) common aim
e) common team

4. In which of the alternatives does the $/ \mathrm{t} /$ phoneme can change into $[\mathrm{k}]$ ?
a) smart teacher
b) smart lad
c) smart ass
d) smart enemy
e) short cut 
5. In which of the alternatives does the /d/ phoneme can change into $[\mathrm{g}]$ ?
a) had stopped
b) had aided
c) mad idea
d) had gone
e) sad uncle

6. In which of the alternatives does the $/ \mathrm{n} /$ phoneme can change into [y]?
a) call girl
b) golden gate
c) cold slaw
d) iron door
e) bud oil

7. In which of the alternatives does /s/ phoneme can change into [S]?
a) nice shoes
b) bus form
c) dress stitch
d) space sack
e) boss order

8. In which of the alternatives does the /z/ phoneme can change into [3]?
a) nose drip
b) prose tone
c) cheese price
d) rose show
e) peace talk

9. In which of the alternatives does the $/ \theta /$ phoneme can change into $[\mathrm{s}]$ ?
a) tooth ache
b) smooth case
c) both sides
d) growth rate
e) earth matters

10. In which of the alternatives does the $/ \mathrm{t} /$ phoneme can change into $[\mathrm{p}]$ ?
a) best object
b) direct method
c) pocket size
d) mixed identity
e) fast horse

11. In which the alternatives does /d/ phoneme can change into [b]?
a) card unit
b) head ache
c) blood flow
d) old trick
e) good morning

12. In which of the alternatives does the $/ \mathrm{n} /$ phoneme can change into [m]?
a) open door
b) brown bear
c) sun set
d) tin soldier
e)green eel

13. In which of the alternatives does the /s/ phoneme can change into [ $]$ ?
a) ice year
b) face value
c) dress price
d) address direction
e) S.O.S note

14. In which of the alternatives does the /z/ phoneme can change into [3]?
a) apologize to
b) buzz time
c) those yogurts
d) close distance
e) antifreeze liquid

15. In which of the alternatives does the $/ \theta /$ phoneme can change into $[\mathrm{s}]$ ?
a) earth economy
b) North winds
c) South Pole
d) birth season
e) fourth aim

16. In which of the alternatives does the / $/$ / phoneme can change into [p]?
a) post office
b) most of them
c) lost country
d) hot dog
e) put by 
17. In which of the alternatives does the /d/ phoneme can change into [p]?
a) broad terms
b) lord mayor
c) bird nest
d) card gamble
e) ten inns

18. In which of the alternatives does the $/ \mathrm{n} /$ phoneme can change into [m]?
a) Roman road
b) blind spot
c) foreign mission
d) a kind offer
e) a mine digger

19. In which of the alternatives does the $/ \mathrm{t} /$ phoneme can change into $[\mathrm{k}]$ ?
a) a fat girl
b) a street sweeperc) a flat line
d) that boy
e) sit in

20. In which of the alternatives does the /d/ phoneme can change into $[\mathrm{g}]$ ?
a) a sad horse
b) land mines
c) a kind offer
d) a red carpet
e) a sand tower

21 . In which of the alternatives does the $/ \mathrm{n} /$ phoneme can change into [ $\mathrm{y}]$ ?
a) a common aim
b) a fun story
c) a garden gate
d) some keen remarks
e) a main item

22. In which of the alternatives does the /s/ phoneme can change into [J]?
a) a cross sign
b) a gross tax
c) a gross blessing
d) a mass gathering
e) a 'Miss Youth' contest

23. In which of the alternatives does the $/ \mathrm{n} /$ phoneme can change into[m]?
a) condition
b) conquer
c) consist
d) confirm
e) concern

24. In which of the alternatives does the $/ \theta /$ phoneme can change into [s]?
a) health care
b) health club
c) health service
d) hell theme
e) heart-to-heart

25 . In which of the alternatives does the $/ z /$ phoneme can change into [3]?
a) bruise pain
b) buzz you
c) bronze statue
d) fizz of gas
e) breeze into

\section{Pretest ANSWERS}

\begin{tabular}{|c|c|c|c|c|}
\hline 1. D & 6. B & 11. E & 16. $\mathrm{E}$ & 21. C \\
\hline 2. A & 7. A & 12. $\mathrm{B}$ & 17. $\mathrm{B}$ & 22. $\mathrm{E}$ \\
\hline 3. $\mathrm{C}$ & 8. D & 13. A & 18. C & 23. D \\
\hline 4. E & 9. $\mathrm{C}$ & 14. C & 19. D & 24.C \\
\hline 5. D & 10. B & 15. D & 20. B & 25. B \\
\hline
\end{tabular}




\section{Appendix B}

\section{A Posttest on Phrasal Assimilation}

1. In which of the alternatives does the / $\mathrm{t} /$ phoneme can change into [p]?
a) an advanced method
b) an adult story
c) an advanced fever
d) an adult affair
e) a benefit instance

2. In which of the alternatives does the $/ \mathrm{n} /$ phoneme can change into[m]?
a) a noon brake
b) a keen vengeance
c) a cannon team
d) a canteen mouse
e) a town center

3. In which of the alternatives does the /d/ phoneme can change into $[\mathrm{b}]$ ?
a) a food supply
b) a food additive
c) a mood spoiler
d) a method effect
e) a food basket

4. In which of the alternatives does the $/ \mathrm{n} /$ phoneme can change into $[\mathrm{m}]$ ?
a) a cotton thread
b) a cotton mill
c) a cotton shirt
d) a button nose
e) press the button

5. In which of the alternatives does the $/ \mathrm{t} /$ phoneme can change into $[\mathrm{k}]$ ?
a) a fruit fly
b) cat food
c) a fruit smell
d) a fruit gallery
e) a cat owner

6. In which of the alternatives does the /d/ phoneme can change into $[\mathrm{g}]$ ?
a) the second girl
b) a blind panic
c) the second war
d) a blind faith
e) a second vacation

7. In which of the alternatives does the $/ \mathrm{n} /$ phoneme can change into [m]?
a) a common problem
b) a wooden slipper
c) a common value
d) a modern society
e) a sudden change

8. In which of the alternatives does the $/ \mathrm{n} /$ phoneme can change into [ $\mathrm{y}]$ ?
a) a maiden name
b) a newborn idea
c) a maiden problem
d) a newborn kid
e) a newborn son

9. In which of the alternatives does the /s/ phoneme can change into [S]?
a) toss a pancake
b) toss your hair
c) toss something off
d) toss and turn
e) toss something around

10. In which of the alternatives does the /z/ phoneme can change into [3]?
a) squeeze a bit
b) squeeze so much
c) squeeze more information
d) squeeze on public sector
e) squeeze your eyes

11. In which of the alternatives does the $/ \theta /$ phoneme can change into $[\mathrm{s}]$ ?
a) tenth year
b) tenth floor
c) tenth century
d) tenth day
e) tenth month 
12. In which of the alternatives does the $/ \mathrm{n} /$ phoneme can change into [m]?
a) a fun day
b) more fun
c) fun to be
d) a fun fair
e) fun to win

13. In which of the alternatives does the /d/ phoneme can change into $[\mathrm{g}]$ ?
a) a good gain
b) household goods
c) good and evil
d) a good day
e) good and bad

14. In which of the alternatives does the $/ \mathrm{n} /$ phoneme can change into [ $\mathrm{y}]$ ?
a) a thin plan
b) a tin can
c) to take the train
d) plans to retire
e) a plane ticket

15. In which of the alternatives does the /s/ phoneme can change into[f]?
a) Miss Brown
b) a bus trip
c) a success story
d) business with a company
e) Miss Smith

16. In which of the alternatives does the /d/ phoneme can change into [b]?
a) hand down to
b) a handshake
c) a land mine
d) a sandstorm
e) the northern star

17. In which of the alternatives does the /z/ phoneme can change into $[\mathrm{Z}]$ ?
a) where's yours?
b) those roses
c) whose mistake?
d) please see it
e) a kissing scene

18. In which of the alternatives does the $/ \mathrm{T} /$ phoneme can change into $[\mathrm{s}]$ ?
a) a depth problem
b) north-south war
c) a death threat
d) death bed
e) a heart attack

19. In which of the alternatives does the /d/ phoneme can change into $[\mathrm{b}]$ ?
a) a hard copy
b) a candid camera
c) a posted letter
d) a head master
e) what kind of dog?

20. In which of the alternatives does the /t/ phoneme can change into [p]?
a) a market director
b) a mixed shape
c) split personality
d) a short trip
e) a fast change

21 . In which of the alternatives does the $/ \mathrm{T} /$ phoneme can change into $[\mathrm{s}]$ ?
a) a health problem
b) a health care
c) a health club
d) a health insurance
e) a health security

22. In which of the alternatives does the /s/ phoneme can change into [J]?
a) publish or perish
b) an insurance scheme
c) an access code
d) an insurance firm
d) accuse of 
23. In which of the alternatives does the $/ z /$ phoneme can change into[Z]?
a) a dozen roses
b) a rose year
c) a rose garden
d) a rose show
e) a rose yard

24 . In which of the alternatives does the $/ \mathrm{n} /$ phoneme can change into [m]?
a) a throne candidate
b) a throne calendar
c) a throne member
d) a throne damage
e) a throne game

25. In which of the alternatives does the $/ \mathrm{n} /$ phoneme can change into[m]?
a) The main value
b) the main problem
c) the main access
d) the main cannon
e) the main help

\section{Posttest: ANSWERS}

\begin{tabular}{lllll}
\hline 1. $\mathrm{A}$ & 6. $\mathrm{A}$ & 11. $\mathrm{C}$ & $16 . \mathrm{C}$ & $21 . \mathrm{E}$ \\
2. $\mathrm{B}$ & 7. $\mathrm{C}$ & 12. & $17 . \mathrm{A}$ & $22 . \mathrm{B}$ \\
3. $\mathrm{E}$ & 8. & 13. $\mathrm{A}$ & $18 . \mathrm{B}$ & $23 . \mathrm{D}$ \\
4. $\mathrm{B}$ & $9 . \mathrm{B}$ & $14 . \mathrm{B}$ & $19 . \mathrm{D}$ & $24 . \mathrm{C}$ \\
5. $\mathrm{D}$ & $10 . \mathrm{E}$ & $15 . \mathrm{E}$ & $20 . \mathrm{C}$ & $25 . \mathrm{A}$ \\
\hline
\end{tabular}


